\title{
Paradise Lost? Postwar Memory of Polish Jewish Survival in the Soviet Union
}

\author{
Laura Jockusch \\ Hebrew University \\ Tamar Lewinsky \\ University of Basel
}

\begin{abstract}
The vast majority of Polish Jews who survived the Holocaust owed their survival to their flight or deportation to the Soviet Union. Yet, their story figured little in early postwar commemoration in the Displaced Persons camps of Germany and in survivor communities in Poland and elsewhere. Using new source material to provide an internal perspective on these communities, the authors argue that the downplaying of the Soviet experience in public memory was politically and ideologically motivated and was determined by the larger context of postwar politics.
\end{abstract}

\section{Introduction}

In the opening sequence of Saved by Deportation, a recent documentary film on Polish Jews who survived the Second World War by escaping to the Soviet Union, interviewee Asher Sharf recalls: "In Russia, I thought, 'I'm going to write a book of every day that I was in Russia.' But when I came back to Poland, I saw what happened and I thought that [in the Soviet Union] I was in heaven." Sharf never chronicled his experiences in book form, but filmmakers Sławomir Grünberg and Robert Podgursky recorded his return journey, together with his wife Shyfra, to the places deep in the Soviet Union where they had lived during the war. ${ }^{1}$

The families of Shyfra and Asher were among the 350,000 to 400,000 Polish Jews-including those who had fled in advance of the Germans-who found themselves on the territory of eastern Poland shortly after the invasion began. ${ }^{2}$ After the Soviet and German partition of Poland, the Jewish population of the Soviet portion became Soviet citizens, though some were arrested and thousands were deported to remote internal frontiers as "class aliens." Of those who fled the German portion of Poland between 1939 and 1941, a considerable number (possibly as many as $100,000^{3}$ ) were deported as class aliens, and a large number were evacuated or successfully fled the German invasion. We may never know the actual figures, but we can say that many thousands died as exiles or evacuees, and many thousands more who failed to evacuate in time were murdered by the Germans 
and their allies. The deportees' status changed when, one month after Nazi Germany's June 22, 1941 declaration of war on the Soviet Union, the Soviet government renewed diplomatic relations with the Polish government, now a government-in-exile in London. Imprisoned Polish citizens soon were released on the basis of a bi-lateral agreement. ${ }^{4}$ As citizens of an allied state, Polish exiles now were able to make their way south to Soviet Central Asia in search of better circumstances. Whether in urban centers such as Samarkand or in kolkhozy (collective farms), they faced poverty, hunger, and epidemics. Yet, families remained intact and young people had access to education. Shyfra lived with her siblings, parents, and grandparents in Samarkand, while Asher worked as a truck driver in Tajik Leninabad (Khujand). Their 1945 wedding in Uzbekistan, attended by family members, friends, and guests from among the local population, was almost as festive as the Polish Jewish weddings they had known in prewar Poland.

Like many other exiles, the Sharfs learned about the mass murder of Polish Jews only after they returned to Poland. Naturally, the couple's new understanding of the extent of the destruction led them to re-evaluate their own experiences. Despite its hardships, exile in the Soviet Union now appeared to them to have been gan eydn (paradise). "As soon as we came to Poland," Shyfra Sharf remarks in the film, "we knew that we were the lucky ones by being in Russia, because we survived."

Only about 350,000 of the prewar Polish Jewish population of 3.3 million survived the Second World War. Thirty to fifty thousand of these were liberated in the territory of the prewar Polish state, and an additional seventy to eighty thousand were freed from camps in Germany and Austria. Some 230,000 or more Polish Jews survived in the Soviet Union, and of these an estimated 180,000 opted for repatriation immediately after the war's end-possibly some 200,000 by late 1946. ${ }^{5}$ Thus, the majority of the remnant of Polish Jewry survived the Holocaust only because they had been able to escape eastward-a fact that is often given insufficient weight in contemporary research. In his latest monograph, historian Dan Diner notes the irony in the fact that in popular (Jewish) memory, British Mandate Palestine has come to be seen as the ultimate haven for Jewish survival; in fact, higher numbers of Jews survived the war in the Soviet Union. ${ }^{6}$

In this article, we investigate the ways in which the Jewish experience of exile in the Soviet Union was remembered and described in survivor communities during the early postwar years. By exploring survivors' recollections of Soviet exile, we provide a novel perspective on survival, postwar reconstruction, and the genesis of Holocaust memory. In doing so we seek to raise questions, open up new discussions, and encourage further research on the variety of ways in which Polish Jews who survived the Second World War in the Soviet Union remembered-or chose to forget-this past. ${ }^{7}$

Survivor communities in three different periods and geographical settings serve as a prism for analysis. To explore survivors' collective memories, we draw on 
a wide array of primary source material, including newspapers, memoirs, testimonies, and personal papers. We focus first on liberated Poland during the period 1944-1946, when most of the exiles returned. This early period is characterized by the survivors' immediate confrontation with loss and destruction, as well as by political turmoil in reconstituted Poland. Second, we explore Displaced Persons (DP) camps in Allied-occupied Germany, which served as a temporary haven for the many Jews who had concluded that there was no future for them in Poland. This period proved transitional; most Jewish DPs had left Germany by the end of the 1940s. Nevertheless, it was formative both in terms of making the public aware of the extent of the catastrophe and in terms of establishing an almost canonical understanding of the range of Holocaust experiences. This "canon," if one may call it that, formed the basis for commemorating the recent past. Third, we trace the evolution of memory of the Soviet experience into the 1980s, focusing on the transnational Polish Jewish diaspora into which the former Jewish DPs integrated themselves.

\section{Politically Aligned Memories: Jewish Repatriates in Postwar Poland}

To the remnant of Polish Jewry, Poland in the early postwar period appeared unstable, often hostile, and sometimes unsafe. The German occupation had devastated the country and resulted in the deaths of twenty percent of its civilian population, including three million Jews. Poland's transformation into a Soviet-sponsored Communist state following the liberation from German rule had led to political turmoil and a state of civil war. Political conflict engulfed Polish society. Polish Communists were able to seize power because they enjoyed protection from Moscow, reinforced by the Soviet troops liberating the country. The Communists constituted a small minority, however, and they did not have the support of broad segments of the Polish population. Arrayed against them stood anti-Communist resistance groups and a wide range of political parties loyal to the Polish government-in-exile. To further complicate the situation, Jewish communal organizations received material support from the new Communist government, which sought in this way to mobilize this small segment for service in its administration. ${ }^{8}$ Some opponents of the government held Jews collectively responsible for the Communist system's transgressions. This sentiment was captured in the prewar concept of Żydokomuna (Judeo-Bolshevism), which gained new currency after the liberation. ${ }^{9}$ The combination of this political trope with traditional and economically motivated antisemitism among the Polish population resulted in instances of anti-Jewish violence, and reached a dramatic climax with the Kielce pogrom of July $1946 .{ }^{10}$

Initially, however, the new government's support for the rebuilding of Jewish life gave reason for optimism that there was a future for the Jewish minority in 
Poland and that the community could be reconstructed. In November 1944, with the assistance of the pro-Soviet authorities, Polish Jewish survivors who had had various experiences - camp survivors, Jews who had emerged from hiding places, former partisans, and those who had been drafted into the Anders Army or the Red Army-organized a Central Committee of Polish Jews (Centralny Komitet Żydów Polskich-CKŻP). The committee served as an official representative to the government, oversaw social welfare and education, and established an independent rabbinate. ${ }^{11}$ Similarly, in the formerly German territories that Poland had acquired after its borders were moved westward, the government's support in rebuilding Jewish communities was understood as a welcome form of tutelage. These newly established communities in Lower Silesia and Pomerania absorbed the majority of the 180,000 repatriated Polish Jews who arrived from the Soviet Union between February and September $1946 .{ }^{12}$

The Jewish population in Poland grew immediately after the war's end due to the return of both camp survivors and exiles repatriated from the East. But after reaching a peak in the summer of 1946 it decreased dramatically. The encounter with the almost total destruction of Polish Jewish life and the ongoing antisemitic threat, combined with economic hardships and housing and food shortages, motivated the repatriated exiles and survivors of Nazi occupation to migrate westward. ${ }^{13}$ With help from the Brichah, a clandestine Zionist movement channeling illegal immigration to Palestine, tens of thousands of Jews left Poland. The majority of those who returned from the Soviet Union stayed in Poland only a few weeks or months before moving on. ${ }^{14}$ As a result, during the years 1944 through 1946 the Jewish population in Poland was in constant flux. An estimated 260,000 to 280,000 Jews passed through during this period. ${ }^{15}$

Despite the demographic instability of Polish Jewish communities, a rich cultural life began to develop under the auspices of the CKŻP as early as fall 1944 . The documentation and commemoration of the recent past figured prominently in these activities. Notably, the Central Jewish Historical Commission, founded in Lublin in December 1944 and headed by the historian Philip Friedman, collected large numbers of survivor testimonies and Nazi documents to provide an accurate account of the destruction of Polish Jews. By the end of 1947, the commission had collected nearly three thousand testimonies and published thirty-nine books. A variety of Polish and Yiddish newspapers-most prominently Dos naye lebn-dealt with aspects of the Nazi genocide. Yizker (memorial) books published by survivors in Poland and elsewhere focused on the history and destruction of specific villages, towns, and regions. ${ }^{16}$

An examination of the ways in which repatriated Polish Jews participated in these reflections reveals that the experience of wartime survival in the Soviet Union is presented in a distinctly political light. Strikingly, those who had experienced the worst of the Soviet regime-forced labor, hunger, and disease, severe 
material deprivation, and antisemitic violence-did not commit their stories to paper. Several factors may have contributed to their reticence. In their deep shock over the total annihilation of their families and communities, the returnees may have felt that their suffering was relatively minor, and therefore unworthy of commemoration. In many cases, refugees simply did not have time between repatriation and subsequent flight to the West to record-let alone publish-their experiences. This was especially true of those who arrived in Poland in the atmosphere of panic that followed the Kielce pogrom of July 4, 1946. Yet, perhaps most influential in this tendency was the growing political pressure that accompanied Poland's alignment with the Soviet Union. By the spring of 1947, Poland had been transformed into a one-party Communist regime; for Jews as for others, shedding negative light on the Soviet Union by spelling out the hardships that they had endured there would have been politically inopportune or even dangerous.

It is not surprising, then, that in the Yiddish-language press in the new Poland the discussion of survival in the Soviet Union was dominated by those whose experiences had been positive. Spared from forced labor, and in many cases affiliated with Soviet state or Party institutions, these returnees had reason to praise the Soviet regime as their savior. Thus, when discussing the fact that some 230,000 Polish Jews had survived the war in the Soviet Union, Dos naye lebn, the official organ of the Central Committee in Łódź, adopted a tone of gratitude. Contributors tended to exaggerate the benefits of agricultural work and the educational and cultural opportunities that some of the exiles had enjoyed. They asserted that, for the exiles, eagerness to return to Poland was rooted in a deep sense of duty towards those who had perished and in a commitment to contribute to the rebuilding of Jewish life on Polish soil. ${ }^{17}$ In a 1947 article on the support Polish Jewish students enjoyed in Soviet universities, Yitskhok Varshavski praised the "hospitable Soviet soil," which had received the "refugees from Poland, the victims of fascism" with great understanding and "fatherly guidance." He went on to say that not only had Polish Jews enjoyed full civil rights, but that their quest for access to higher education, which had been limited in interwar Poland, had been fulfilled. ${ }^{18}$

Other voices emphasized Polish Jews' contributions to the fight against fascism as soldiers serving in the ranks of the Red Army. As one journalist remarked in May 1947, "in all European countries where a Jewish heart was beating, eyes were directed to the East, whence the entire Jewish people expected salvation and the end of Nazism." Jews were eager, the author argued, to join the ranks of the Soviet army in return for their physical rescue. ${ }^{19}$

The Polish Jewish historian Ber Mark, an affiliate of the Jewish Anti-Fascist Committee in Moscow, emphasized the similarities between Polish Jews' service in the Red Army and Jewish resistance in the ghettos. Jewish Red Army soldiers "gave their young lives for the same cause as did Mordechai Anielewicz.... It is 
difficult to measure self-sacrifice and heroism. The circumstances are different; the former reaches sanctification, the latter only bravery." Thousands of devoted young men and women "endured the entire glorious path from Stalingrad to BerlinJews rewarded with the highest state decorations, Jews whose names are forever tied to battles and victories in East Prussia and at the Vistula, in the very territory of the enemy in Germany and at the Baltic Sea."20

An ideologically aligned narrative of the recent tragedy had to encompass the youngest generation as well. A Yiddish textbook for elementary schools published in 1947 by the education department of the CKŻP contains a short story about a boy named Arele and his return from Bukhara. Arele was still a toddler when his parents escaped with him to the Soviet Union. Although his mother died in Central Asia when he was very young, he treasures warm childhood memories: "There was so much light, such a big sun, and there was 'uruk' ... and 'kishmish' and 'dinies'[exotic prune-shaped fruit; raisins; pineapples], and when you rode an 'ishak' [donkey], you spurred him: 'khik, khik, khik'!... There was also little Yusuf who had a brother named Sharifka." He adds: "I love Bukhara and I will always love it." ${ }^{21}$ There is no mention of hardship, no explanation of his mother's death. His friendship with local children and the abundance of nature are at the core of Arele's recollections.

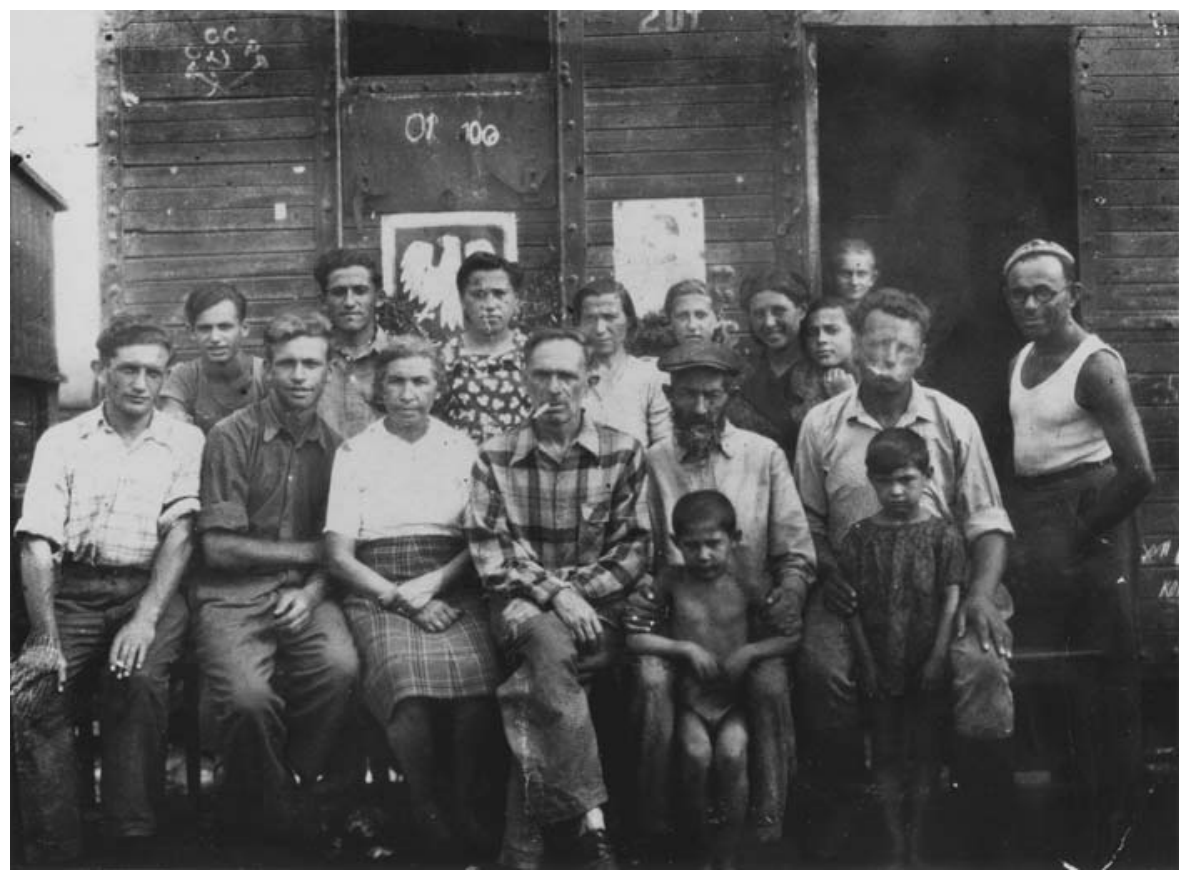

Jewish deportees wait at a train station in Kazakhstan in 1946 for their return to Poland. USHMM, courtesy of Aaron Yermis. 
When Arele travels back to Poland together with his father, the train is greeted by friendly Poles who sell, among other things, fresh fish. The boy is fascinated by the streetcars in Warsaw, which are so unlike the donkeys and camels in Bukhara. Yet, he is sobered when he begins to learn more about the recent past. Of Arele's family, only his father's brother survived and, when the three of them visit the remains of the Warsaw ghetto, the little boy becomes very sad. Only rubble remained of his parents' home on Zamenhof Street, which he had known so well through their stories. Looking at the ruins, Arele tells his father he wants to become an engineer so that he can help rebuild houses. The story's author insinuates, without subtlety, that Polish Jewry should be part of the new Polish society and should help to rebuild Jewish life. The last part of the story describes Arele's first day at the Yiddish elementary school in Warsaw. The teacher, a friendly, motherly woman, asks every child to say a little about himself. After his visit to the location of the former ghetto, Arele is unable to tell her about Bukhara. Yet he does confide his wish to study hard and to become an engineer. ${ }^{22}$ Here again, the hardships Jews experienced in the Soviet Union are downplayed.

Although the majority of Jewish writers who saw their works published had survived the war years in the Soviet Union, it is noteworthy that the encounter with destruction in Poland was most prevalent in the prose and poetry of the immediate postwar years. ${ }^{23}$ As Magdalena Ruta's recent study has shown, the topic of the Holocaust dominated in the pages of the monthly publication Yidishe shriftn (Jewish Writings), as well as in the two-volume Yiddish-language anthology published under the same title by the re-established Association of Yiddish Writers and Journalists in Poland. Early postwar Jewish writing published in Poland was a literature mainly of mourning and commemoration, fulfilling an almost liturgical function. $^{24}$

Ideology and the exigencies of Socialist Realism seem to have permeated prose more easily than poetry. In poetry, as in prose, writers emphasized the physical beauty of the USSR. Yitskhok Perlov, for example, described the Amu Darya and Syr Darya rivers in Central Asia, which to him were as beautiful as the "silver bracelets on the Uzbeks" arms" and shimmered "like necklaces made of coins on the neck of the Turkmens/like the rings of the Kazakhs, like the Tadjiks' earrings...."25 As a privileged refugee affiliated with the Jewish Anti-Fascist Committee in Moscow, he was grateful for what in his eyes was a fraternal sharing of hardship and resources. Nonetheless, many of his poems focus on notions of homelessness, loneliness, and fear-themes that are prevalent in poetry dealing with the exile in the Soviet Union, for example in the works of Reyzl Zhikhlinski, Khayim Leyb Fuks, and Rokhl Korn. ${ }^{26}$

Prose from the period about the sojourn in the Soviet Union tends to highlight the positive effects of the Soviet surroundings on the exiles. ${ }^{27}$ One of the leading ideologues of Socialist Realism was journalist Dovid Sfard, a former 
secretary of the pro-Soviet Linke shrayber-grupe (Left Writers' Group) in Warsaw. While in Moscow during the war, he joined the Union of Polish Patriots-a body whose former members came to control the pro-Soviet government in postwar Poland. Sfard was among those who emphasized the uplifting aspects of the encounter with the Soviet environment. In an article on the repatriation of Polish Jewish intellectuals he reflected upon the mission of carrying the torch of Soviet culture back to Poland:

Only a small remnant of Yiddish writers from Poland [survived]. This is virtually all that has remained of Polish Yiddish literature. But the Soviet country did not merely save our bodies but also our souls, our belief in humanity, in our own future, in the possibility of living and writing anew.... Our group of writers returned to the ruins of the former Polish homeland from the hospitable Soviet Union, not only freshly fostered, but especially intellectually edified and enriched in their creativity and ready to serve our people immediately. ${ }^{28}$

Yet, the type of ideological writing that Sfard envisioned became predominant in Yiddish publishing in Poland only in $1949 .{ }^{29}$ By that time most writers had fled westward, along with the majority of Polish Jews. ${ }^{30}$

\section{Memories in Transition: Polish Jewish Exiles in the DP Camps of Occupied Germany}

The exodus from Poland led to a dramatic growth in the Jewish DP population in the western zones of occupied Germany, from over 50,000 in December 1945 to an estimated 200,000 in spring $1947 .{ }^{31}$ There are no precise figures on the percentage who had survived in Soviet exile, but according to various estimates repatriated Jews made up two-thirds of the entire Jewish DP population and 85 percent of the Polish Jews among the DPs. ${ }^{32}$ It would seem, then, that among the Jewish DPs the memory of Soviet exile should have been at least as prominent as that of other wartime experiences. Given that they no longer had to fear state repression, we might expect them to have spoken more freely and critically about their experiences. Yet, there is little evidence that the growing distance in geography and time in fact encouraged them to reflect anew on their Soviet past.

Some voices among the Jewish DPs noted the relative lack of attention to the Soviet experience in the public memory of the She'erit hapletah("surviving remnant" ${ }^{33}$ in Germany. In 1947, journalist Mordkhe Libhaber opined that the survivors in the DP camps had not adequately addressed Soviet exile. He saw this as a paradox, since he was aware that Polish Jews who had survived in the Soviet Union constituted the majority of the displaced Jews in Germany. Libhaber, himself a survivor of the Stalinist gan eydn, viewed the omission of this central aspect of the recent past as an alarming development. In his words, "losing the past means neglecting the future. Neglecting the past means losing the future."34 In an effort to reverse the trend, Libhaber launched an appeal to the readers of 
Ibergang (Transition), the organ of the Association of Polish Jews in Germany. "The issue of this period is multifaceted and therefore a delicate one," Libhaber cautioned. He went on to explain:

Hundreds and thousands of Jews returned from the Soviet Union, saved from certain death under Hitler. A feeling of strong gratitude towards the Soviet government, mixed with accusations against it, is part of the problem. Many experienced a historical irony. They were led to destruction through hard labor in the camps where they were saved from death. Many found a hospitable asylum in the Soviet Union when they escaped hell. We understand the feelings of both gratitude and accusation, but neither should prevent the important and objective memorialization of the experiences in Russia in the years 1939 to $1945 .{ }^{35}$

Libhaber rightly pointed out that the number of DP writers who addressed the Soviet experience was not in proportion to the number of DPs who had survived there. However, those who did address Soviet wartime experiences did so from a variety of perspectives, underlining the ambiguity of salvation and suffering under the Soviets.

As in Poland, some DP Jewish writers with Communist leanings praised the Soviets as heroes. Yitskhok Perlov, who had written about his Soviet experiences while still in Poland, maintained his positive view as a DP in Germany. In a poem composed in Berlin in 1946, Perlov lauded the Soviet Union for its role as savior and liberator. He eulogized the Soviet Union as similar to a Noah's ark, saving the children of Abraham from the deluge of Nazism. ${ }^{36}$ He venerated the Soviets as liberators not only of Europe, but most particularly of the Jews. In a poem published in his 1947 collection Undzer like-khame (Our Solar Eclipse), Perlov retained the laudatory tone he had used while in Poland: "Yes, Moscow is the epitome of liberty/London, Warsaw, Tel Aviv because of you are free..../I bless your soil today, your seed today is blessed/Those who detest you, Russia, their name shall I detest." 37 The majority of the poems in this collection were written during Perlov's years of exile in Soviet Central Asia between 1941 and 1945. It is telling that he decided to have them published along with poems he wrote after he left postwar Poland. ${ }^{38}$

Yet, other writers avoided ideological shading in their descriptions of life in Soviet exile. Writer Mendel Mann — a veteran of the Red Army_refrained entirely from using political rhetoric in his series of poems "Af rusisher erd" (On Russian Soil), which appeared as part of his 1947 book Yerushe (Heritage). Mann offers his most intimate recollections of life in exile, including the joyful birth of his son in February 1942. ${ }^{39}$ Some writers in the DP camps provided a more nuanced picture by addressing the hardship, suffering, and victimhood that had characterized Jewish survival in the Soviet Union. For example, Meylekh Tshemni's Uzbekistan - first published as a series in Dos vort, the Munich-based organ of the Po'ale Zion party and published in book format in 1949—-spoke to the hardships 
that made the Soviet experience another instance of Jewish martyrdom. As Tshemni explained in his introduction, the series was based on his personal recollections of the "graves in Uzbekistan where Jewish martyrs rest, displaced by the Hitler-beast... These martyrs, too, must be commemorated." ${ }^{40}$ Tshemni's colleague, the poet and former partisan Szmerke Kaczerginski, acknowledged this call to include the victims of Soviet exile into the martyrology common in the DP camps. After reading Uzbekistan, Kaczerginski wrote to Tshemni, crediting him for being the first to render Jewish exile in Soviet Central Asia as a motif of Yiddish prose fiction: "You are the first who at least tells three-quarters of the truth about Jews not only being saved in the [Soviet] 'paradise,' but also about Jews suffering, dying, and such. I would very much like you finally to tell the whole truth in your descriptions.... One also has to tell how Jews in the 'little paradise' were in hell." ${ }^{41}$

Survivors recorded their memories not just in literary works, but also in testimonies. The Central Historical Commission in Munich, the primary Jewish DP institution dedicated to documenting and researching the recent past, collected more than 2,500 testimonies in the DP camps between late 1945 and early $1949 .{ }^{42}$ While these testimonies contain a wide variety of narratives of Jewish survival, only a few dozen address the topic of Soviet exile.

A prominent theme in those testimonies is the Polish Jewish exiles' service in the Red Army and their heroic contribution to the liberation of Europe. ${ }^{43}$ One such soldier was Eliezer Ushtun, born in 1921 in Lemberg (Lwów), who escaped to the Soviet Union after the German invasion. Ushtun described working in the mines in the Donbas and being drafted into the Red Army. He fought at the front in a unit that liberated three concentration camps-one near Danzig and two in Mecklenburg; in the Mecklenburg camps Ushtun encountered Jewish survivors. He returned to Poland after he was demobilized in September 1945, leaving for Germany with a kibbutz group after only two months. ${ }^{44}$

Other accounts focus less on battlefield experiences than on suffering and victimization, including stories of children losing their parents to violence or epidemics. ${ }^{45}$ The testimonies also address the antisemitism the survivors had encountered in the Soviet Union from the local population and from other refugeesmostly non-Jewish Poles. ${ }^{46}$ Some depict the randomness of deportation from the Soviet-occupied eastern borderlands of Poland into the interior of the Soviet Union-deportations that despite all appearances turned out to be a salvation. Simkhe Binshtok, born in Poland in 1936, describes his family's escape to Brest-Litovsk and subsequent deportation to Siberia. "They sent us away like sheep. We had to take several trains until we arrived in a deep forest with foreign faces, foreign languages, in a wooden barrack," the boy recalled. The family was subjected to forced labor and suffered many hardships. Binshtok was separated from his parents, but later was reunited with them in Tashkent. Their hopes to 
leave for Iran thwarted, the family left for Leninabad, where they spent the rest of the war period. Returning to Poland in 1945, they learned that, except for one grandmother who lived in Jerusalem, all of their family members had been murdered. ${ }^{47}$ Similarly, a testimony by a DP student then in Stuttgart related his family's exile in the Caucasus and Central Asia, where they faced hunger, illness, and separation, and where his father was drafted into the Red Army. The young man concludes his testimony laconically: "That's how distress and hunger were inflicted upon us for three years between 1942 and 1945. Then we all left healthy for Poland, but there the tragedy had happened and of our dear ones no-one was left. It was Huttler [sic] who made this tragedy." 48

Overall, however, writings about the exile, whether in the form of lyrical or fictional renditions or of testimonies, appear to have played a relatively minor role in the otherwise prolific literary creativity of the DPs. The most obvious explanation for this striking omission seems to lie in the composition of political leadership in the camps. Those who emerged as the founders of DP institutions, most notably the Central Committees of Liberated Jews in the British and American Zones, shared the experience of having survived under Nazi occupation. These communal leaders belonged to the earliest cohort of survivors to populate the DP camps. Early structures of self-governance came into being shortly after the liberation of concentration camps on German soil. In the American Zone, Jews of Lithuanian origin liberated from Dachau formed a strong Zionist leadership cadre. ${ }^{49}$ Similarly, in the British Zone former prisoners of Bergen-Belsen constituted an elite who would preside over the Jewish population of the entire zone. ${ }^{50}$ By early 1946, when the first waves of Polish Jews repatriated from the Soviet Union arrived in Germany, the main Jewish institutions had been formed and leaders had emerged. Historian Ze'ev Mankowitz asserts that "refugees" and "direct survivors" differing experiences "did not translate into a power struggle between the two groups." The repatriated Jews tended to accept the leadership of those who had arrived before them: "There was a lot they shared in common and, as a rule, the repatriates who bore their own freight of guilt for those they had left behind when they fled eastwards accepted the moral leadership of those "who had been there." "51 "Direct survivors" continued to constitute the majority of the leadership; even in 1948, in the third elected Central Committee of Liberated Jews in the American Zone, only three of fourteen committee members had survived the war years in the Soviet Union. ${ }^{52}$ Until the dissolution of the She'erit hapletah in Germany, leadership of the Jewish DPs remained principally in the hands of those who had suffered directly from Nazi persecution.

More complex explanations for the lack of attention to the experience of Soviet exile go beyond political conditions in the camps and involve processes of identity formation and commemoration. The most influential factor here was the "hierarchy of victimhood" that prevailed in survivors' thinking. The differing 
Holocaust experiences appear to have divided DP society and fostered a hierarchy of suffering, with concentration camp survival at the top and the Soviet experience at the bottom. This "competitive suffering" manifested itself in various ways. For example, the Central Historical Commission deliberately shifted attention away from the story of Polish Jews in the Soviet Union. Founded in November 1945 by East European Jews who had survived camps and ghettos or had come out of hiding, the commission sought to document the catastrophe through eyewitness testimonies, questionnaires, documents, and artifacts. Neither the detailed questionnaires asking survivors to relate their experiences of German occupation, nor the commission's public appeals to survivors to record their personal experiences in writing covered Jewish exile in the Soviet Union. The exile did not figure at all in the commission's own historical periodical, Fun letstn khurbn (From the Latest Destruction), edited by journalist and history teacher Israel Kaplan. This periodical, designed to encourage Jews to join in the work of collecting and chronicling the catastrophe, featured eyewitness testimonies, documents, and local and regional studies on ghettos and camps. ${ }^{53}$ Kaplan's personal agenda, it seems, was to create a canon of "legitimate" Holocaust experiences - a canon that included survival in ghettos and camps, survival among the non-Jewish population under false identities, and participation in partisan units. These were the experiences shared by the commission activists and the wider leadership circles of the She'erit hapletah. Reports submitted on survival in the Soviet Union did not see publication; Kaplan apparently did not deem them a valid part of the Holocaust experience. ${ }^{54}$

Yet another reason for the virtual exclusion of the Soviet experience from public discourse seems to be that survival in the Soviet Union did not lend itself to ritualization to the extent that other Holocaust experiences did. In the immediate aftermath of the war, Jewish DPs were preoccupied with commemorative events centered on local remembrance days and anniversaries of major ghetto uprisings. Soviet exile, however, did not offer specific dates or places for commemoration. The objects of memorialization among the Jewish DPs were loss and destruction, not survival. ${ }^{55}$ In the perception of the "survivors," the story of the "refugees" was one of survival through hardships that did not seem directly related to the Holocaust. The Nazis murdered between 2.8 and 2.9 million Polish Jews, whereas the number of deaths among Jewish exiles in the interior of the USSR appears to have been in the tens of thousands. ${ }^{56}$ Hence the "weight" of suffering seemed to express itself in the numbers of those who had been murdered. Yet, these factors do not sufficiently explain the marginalization of the suffering of Polish Jews who had sought refuge or were forcibly exiled under Soviet rule. The relativity of suffering that seemed to rank camp survival over exile cannot by itself explain the absence of the Soviet experience in literature and testimonies.

In the DP camps, commemoration took place usually within the context of landsmanshaftn (hometown societies). Many towns kept local commemorative 
calendars to mark traumatic events such as Aktionen and the liquidation of ghettos. An invitation published in Ibergang in February 1947 typified these efforts: "Attention! Jews of Grodno! Regarding the memorial day of the liquidation of the ghetto Grodno, a memorial observance will be held on Wednesday, March 12, this year in Augsburg, Halderstrasse 8, in the school building. All people from Grodno are requested to participate. For non-local guests, lodging will be provided. [Signed] The Organizing Committee." ${ }^{, 57}$ A similar trend occurred in the publication of yizker books, a genre of memorial literature that originated in postwar Poland and the DP camps. ${ }^{58}$ In grassroots initiatives, networks of former residents of destroyed towns and villages collected stories, documents, photos, and art chronicling the prewar history and the destruction of their places of origin. These books functioned as portable memorials for communities that were now dispersed throughout the world. ${ }^{59}$

Survivors naturally tended to focus on commemorating local experiences; however, the DP leadership had an interest in centralizing and collectivizing the memory of the recent past. It gave priority, therefore, to events that embodied resistance and propagated a general narrative at the expense of local variants. Since Soviet exile had no specific dates or places that memorialized the collective suffering of Polish Jews in the Soviet Union, the memory of those who had succumbed to malnutrition and disease in Siberia or Soviet Central Asia was relegated to the private realm. In most cases, the only "souvenirs" the exiles were able to take with them from Poland were photographs showing families gathered at the graves of the deceased. ${ }^{60}$ The fact that the exiles also mourned family members who had stayed behind in Poland might have enabled them to participate in the local and centralized commemoration events in the DP camps. Yet, this link would not prove strong enough to ensure their integration into the collective mourning. By 1947, most DPs' interest in public commemorative services had waned. Contemporary observers attributed this trend to a sense of general fatigue and demoralization among the survivors. ${ }^{61}$ Indeed, this shift may have been the result of the survivors' prolonged stay in the DP camps and their wish to build a future rather than to encounter the past on a daily basis. A more likely explanation, though, is that the commemorative community and the object of commemoration did not correspond. In 1945 almost all Jewish DPs participating in public memorializations were "survivors" commemorating their experiences. Two years later, when "refugees" made up the majority of the DP population, public commemoration centered on a past that they did not share. ${ }^{62}$

Further, the DP leadership sought to establish an overarching narrative of destruction as a basis for a Jewish national identity. ${ }^{63}$ Through the press, schools, vocational training facilities, and theater, they implemented an educational program instructing the DPs about their moral obligation to commemorate the past. A necessary first step, they felt, was to create a broad base of historical 


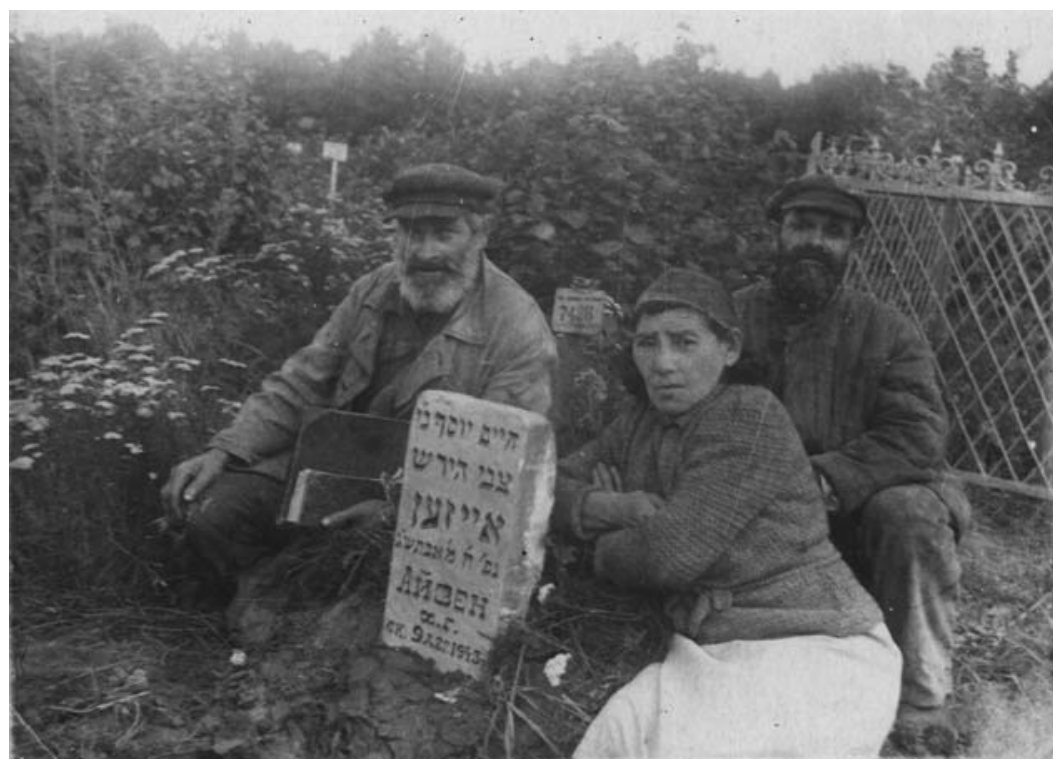

Polish Jewish deportees at the graveside of a family member in Gorkii in 1945. USHMM, courtesy of Ester Ajzen Lewin.

knowledge for those who had no firsthand experience of the ghettos and camps. Lucy Shildkret, a fieldworker for the American Jewish Joint Distribution Committee (who as Lucy Dawidowicz would become an acclaimed historian), was astonished to see survivors portraying their camp experiences in a Yiddish theater performance in Munich. In a personal letter she recalls a conversation with the director, Israel Segal, in which she learned that the play's organizers aimed to educate those who had not shared this experience:

What I couldn't understand was putting such a play in Munich. I could understand it in New York, but here? I talked to Segal about it .... Not much more than about onesixth of the Jews in the American Zone, and perhaps even less in Munich proper, were through the German camps. Most of those still alive lived in Russia through the war or as Aryans outside of ghettos. Therefore, they do not know what the death camps were like.... Because of this, this particular play was put on. A sort of "Lest we Forget" idea. The theatre itself, a rather famous German building, was packed; at least 1,000 people, I would estimate; possibly more. Much sniffing and sobbing throughout. ${ }^{64}$

Thus, an accepted range of Holocaust experiences emerged through public gatherings, theater performances, and newspaper articles. The experience of Soviet exile was excluded, and the minority expected the majority to adopt a Holocaust experience that was not theirs.

In addition, the climate of growing Cold War antagonism proved highly significant, as biographical ties with the Soviet Union could have a negative impact on 
the survivors' prospects to continue their lives in the United States. These concerns may also explain why the former exiles might have refrained from putting their experiences into writing. In particular, those survivors who hoped to immigrate to the United States feared that displaying any sympathies for the Soviet Union might have a negative impact on their chances of being admitted. ${ }^{65}$

In this light, it is telling that when filing with the International Refugee Organization (IRO) for assistance with immigration to North America, the writer Mendel Mann falsified his biographical data. The leftist Polish Jewish writer had been drafted into the Red Army and was one of the leading figures in the reestablishment of Jewish cultural and educational activities in Poland. ${ }^{66}$ Not only had his late arrival in Germany in 1946 undermined his eligibility for immigration to many Western countries, but his alleged flirtation with Communism had damaged his prospects as well. Therefore, when filing in 1948, he inserted biographical information into his application describing himself as a Holocaust survivor who had been in the Warsaw ghetto and was liberated during a death march from the Flossenbürg concentration camp. ${ }^{67}$ In the end, he immigrated to Israel.

Similarly, survivor Meylekh Tshemni's life in the Soviet Union and his literary reflections on this period negatively affected his plan to rebuild his life in the United States. After he filed his application in Germany for an American visa, he was interviewed by an American officer who asked where he had been in the Soviet Union. He declared that he had cleaned toilets, worked as a groom, and been hospitalized in Central Asia; yet, his request was denied. ${ }^{68}$ When he sought to mobilize the American Jewish Labor Committee on his behalf, the institution's representative, Bella Meiskin, told him that he was seen not only as a difficult individual, but also as one affiliated with Communism. ${ }^{69}$ In his memoirs Tshemni recalls the following exchange:

[Meiskin]: There is only one reason: The United States do not admit communists.

[Tshemni]: Right. It's their country. And I thought that Jews returning from Russia [were] no communists anymore. And what do you think for example about me, about my 'Uzbekistan'? [...]

[Meiskin]: Yes, as they say, your book really shows that you are...

[Tshemni]: A communist?

[Meiskin]: I didn't say that. I only say they say. ${ }^{70}$

Because alleged political affiliations did have practical consequences for survivors' efforts to leave Germany, defaming one’s enemies as "communists" seems to have been a weapon in the ideological and personal conflicts that accompanied the dissolution of the She'erit hapletah in Germany. For example in October 1950 
a Munich-based group of kultur-tuers (cultural activists) sent an anonymous letter to Yiddish-speaking intellectuals in the United States. Among the charges they brought against the leading DP authorities was the accusation that the leadership of the (Zionist) United Workers Party (Mapam) in Munich had informed on some leading journalists - among them Mendel Mann—who were trying to get immigration permits for the United States. The Mapam leaders, the anonymous writers alleged, had denounced the journalists as Communists to the local US authorities. One of the individuals concerned had had to abandon his immigration plans on the day of his scheduled departure, and the journalist Mordkhe Libhaber was publicly attacked as a "communist" in front of American military personnel. ${ }^{71}$ For Libhaber and other Jewish DPs who had survived in the Soviet Union, defamation as communists posed a danger to their personal and professional future. This would change in the following decades, however, as public discourse among former exiles came to center around a moral reassessment of the Soviet Union.

\section{Cold War Politics: Evolving Stories of Jewish Victimhood in the Soviet Union}

As the former exiles left Europe and began to rebuild their lives overseas, Cold War tensions were rapidly increasing. Outside the microcosm of the DP camps, growing geopolitical antagonisms provided them an opportunity to re-evaluate the Soviet Union's dichotomous role as both savior and victimizer. Significantly, a critical view of Soviet policies during the war allowed room for a narrative of Jewish suffering during the years of exile. In the United States, by the late 1940s the larger discussion of totalitarian crimes in the Soviet Union had opened a forum for discussion of Soviet "refugee" survivors' suffering. Bundist activists who had survived in the Soviet Union began to comment on the similarity of the Nazi and Soviet camp systems. In his confidential memorandum, "Jewish Exiles in Soviet Russia (1939-1943)," Bundist Jerzy G. Gliksman described the fate of the refugees at the hands of the Soviets in highly negative terms. Writing in the United States, Gliksman portrayed the Soviets as aggressors and the exiles as victims. Not only had he suffered through deportation, labor camps, and imprisonment in Soviet Central Asia, but he had also lost his brother Victor Alter, one of the leaders of the Polish Bund. The Soviet government had executed Alter for unspecified "crimes" in December $1941 .^{72}$ In his 1947 report, Glicksman described the Soviet Union as an oppressive regime almost equal to that of the Germans. ${ }^{73}$ One year later, he published Tell the West, a monograph in which he described his experiences as a slave laborer in the Soviet Union. ${ }^{74}$ In his quest to settle a score with the Soviet regime, he nevertheless expressed his intent not to endanger anyone. He therefore published the names only of those who were "beyond danger, whether through death, distance, or safety of family" - all other names were changed. ${ }^{75}$ In this way he indicated that he still deemed Soviet power a threat to Jews. 
Elsewhere in the Diaspora, the Central Association of Polish Jews in Argentina produced a series entitled Dos poylishe yidntum (Polish Jewry) in the late 1950s and early 1960s. Dedicated to commemorating the life and destruction of Polish Jewry, the series covered a wide range of wartime experiences, including Soviet exile. As part of the series, journalist Betsalel Terkel published two volumes of memoirs. The subtitle of the first, Tsvishn shakaln (Among Jackals [1968]), is itself telling: by distorting the Yiddish term shive madore gehenem (The Seven Compartments of Hell) into shive madore "gan-eydn," he clearly alluded to the contradictory connotations of the Soviet Union as "paradise" and as "hell." In his dedication, Terkel indicates that he intended his book to serve as a "substitute gravestone" for those who had perished in the Soviet Union: "A gravestone to the memory of all of you, Brothers and Sisters who perished-refugees who lost their lives in hunger, suffering, and misery, on the paths of rootless drifting, in the fearful years of wandering and who were not buried according to Jewish burial rites. On your unknown graves in the Siberian taiga and tundra, in the forests ... and steppes - a nameless stone to your sacred memory." ${ }^{76}$ By using the gravestone motif that had also been a common trope in the memory culture of the DP camps, Terkel integrated the Soviet experience into the accepted narrative of Polish Jewish suffering during the Holocaust.

In his introduction to the second volume, published four years later, Terkel emphasized that by writing about Jewish hardships under the Soviets he did not intend to compare the policies of the Soviet regime to those of the Nazis. Rather, he sought to vent his disappointment over the cruel reality that a state that purported to promote freedom, equality, and solidarity in reality acted in direct contradiction to these principles. By retelling this chapter of history he sought to give a balanced and objective view of this particular experience. He mentioned, for instance, that contacts between locals and deportees were sometimes friendly despite the risk they posed to the locals. He even showed compassion for ordinary Russians: "We saw their deplorable miserable life, without a way out, without a hope for better, because life there had been as miserable during the war as it had been before-may this change for the better as soon as possible. This we honestly wish with all our heart to these openhearted, hospitable, compassionate, and wellmeaning Russian people, who all believe that they haven't lived their lives, but have wasted them."77 Ultimately, Terkel was convinced that the Soviet chapter must be remembered as part of the narrative of Polish Jewish suffering, because "a Jewish person with Jewish consciousness must know of all this."78

During the first decades after the Second World War, personal stories of survival in the Soviet Union reached a diminishing Yiddish-speaking audience, and the tenor of these works became increasingly critical of the Soviet Union. In the 
introduction to his autobiographical account of five years in Soviet exile, Polish Jewish journalist Ovadye Feld, who had left the DP camps for Israel in 1951, stated that "the Soviet regime uses every occasion to pride itself that, thanks to the Red Army, millions of Jews in Europe had survived the horrific Nazi period." However, he also asked his readers to consider that under "a different regimeone that respected human beings and human life, the number of victims would have been much smaller." He pointed out that the Soviet regime murdered millions of its own citizens and that the deportation of thousands of Polish Jewish refugees was but one among countless crimes committed by the Stalinist regime. Feld argued that the Soviet regime did not deport Polish Jews with the intent of saving them; that they were saved was a historical accident. ${ }^{79}$

At the same time, some voices in Israel demanded meticulous historical research on Jewish exile in the Soviet Union. In 1958, the historian Meir Korzen urged the readers of the historical periodical of the central Israeli Holocaust memorial and research institute in Jerusalem, Yad Vashem, to undertake thorough research on the fate of Polish Jews in the Soviet Union. Korzen, who presented an elaborate research program for the collection of documentary materials on Jewish refugees in the USSR, voiced his concern regarding the neglect of this chapter of history. He stated: "The life of horror, the dramatic struggle for survival and the premature, bitter end the Jews eventually suffered under the Nazi regime has overshadowed the fate of the Jewish refugees in the Soviet Union, which has consequently been relegated to secondary importance in the mind of the Jewish scholar." Korzen insisted that the collection of evidence from Jewish refugees in the Soviet Union was of utmost importance for the study of the Jewish past, not only because large portions of the surviving remnant of Polish Jewry had shared this experience, but also "because its study reflects particular experiences that have an impact on the present generation and are likely to impress future generations, no less in their way, than do the experiences and consequences of the Nazi regime."

Another example of the radical shift in perceptions of the Soviet Union can be found in the autobiography of Dovid Sfard, who occupied a prominent position in Jewish cultural life in postwar Poland. Like many Polish Jews who remained in Poland after the war, Sfard left for Israel in 1969 in response to a state-sponsored anti-Jewish campaign that began the year before. ${ }^{81}$ In his autobiography, Mit zikh un mit andere (Alone and Together), written in 1976 and published posthumously in Israel in 1984, he critically re-examined his relationship to the Soviet Union. ${ }^{82}$ Although as a writer and active Communist Sfard had been spared hunger and the labor camp during his years in exile, he nonetheless developed an extremely critical attitude toward the regime and its cultural politics.

In 1945 Sfard had praised Socialist Realism for enhancing artistic creativity. Yet, thirty years later he claimed that the normative character of this movement had muted many artistic voices. In retrospect, he asserted that direct contact with 
the Soviet Union during his years of exile had caused his disenchantment with communist ideology. He recalled that he had been appalled by Soviet citizens' internalization of dogmatic beliefs, and observed that it led to "child-like" behavior. Years later Sfard still wondered "whether they behaved this way out of fear or whether they indeed had been infantilized by fear and the prohibition against independent thinking." ${ }^{\$ 3}$ Moreover, he rejected the distorted correspondence between artistic representation and historical reality: "Soviet literature, theater, and film provided models for hyper-humane nobility, but by contrast Soviet life provided models for hyper-inhumane cruelty." 84 According to Sfard, this very cruelty was the reason why the Soviet authorities had initially opposed the repatriation of Jews to Poland. The regime feared that the repatriated Jews would move farther west and disclose information on human suffering in Soviet labor camps in Siberia. With irony, he added that "humanitarian" concerns had also prevented the Soviets from letting Jews return to antisemitic Poland. ${ }^{85}$ Thus, changes in the overall political context, and his experiences in the postwar years, had led Sfard to revise his views drastically.

\section{Conclusion}

The ways in which survivors commemorated Soviet exile depended on the immediate political contexts in which they found themselves after the war, as well as on their personal ideological convictions. In many cases, survivors made pragmatic decisions based on their desire to find some kind of normalcy after what they had endured and to integrate into their new communities. These decisions led them either to emphasize or to downplay their attitudes towards the Soviet Union. In liberated Poland, which in the years 1944-1947 increasingly became aligned with Moscow, those who addressed publicly their survival in the Soviet Union were generally those Jewish intellectuals who had not been victimized and who thus had a positive story to tell.

Although the majority of Jewish DPs who passed through occupied Germany were Polish Jews who had survived in Soviet exile, this distinctive wartime experience did not play a central role in the public memory of the Jewish DPs. The horrific Holocaust experiences of "direct survivors" outweighed and muffled the experiences of Soviet exiles. For both "direct survivors" and "refugees," early Holocaust commemoration centered on loss and destruction rather than on survival. However, when they did recall the conditions of survival, Soviet exile appeared as a "paradise"-gan eydn-in comparison to survival under German occupation. In addition, structural and political conditions in the DP camps and the ideological positions of the survivors, along with the direct impact of the particular political context, prevented the story of Soviet exile from playing a more conspicuous role

in the discourse on the recent past. Those few Soviet exiles who addressed their experiences usually pursued a political agenda. 
Beyond the scope of the DP camps, in the context of Cold War politics, former exiles who had settled outside Poland developed new positions in light of their experiences. Those whose survival in the Soviet Union was accompanied by suffering and ideological disillusionment soon developed critical attitudes toward the regime that had betrayed those it promised to protect. Others, who survived in a privileged position and remained committed Communists for some time after the war, revised their views only in the following decades. Dovid Sfard is a case in point: a committed Communist in the interwar period, he sought to rebuild the New Poland after the war. Not only had he survived thanks to the Soviet regime, but he saw the Soviets as allies in rebuilding Polish society. His departure from Poland and his final disillusionment with Communism led him to revise his previous views. He began to claim that even during the war he had sensed that the Soviet "paradise" had in fact been an illusion.

With the end of the Cold War, the need for justification, political positioning, and settling scores with the Soviet Union became obsolete. The collapse of the Eastern Bloc opened borders and archives and, as exemplified by the journey of Asher and Shyfra Scharf covered in Grünberg and Podgursky's documentary, it rendered the topography of Soviet exile physically accessible. Research institutions began to show interest in interviewing Polish Jewish survivors of exile. Dozens of memoirs and autobiographies by former exiles, most of them written in English or Hebrew, have been published since 1989 in Israel, the United States, Australia, Germany, and the United Kingdom. ${ }^{86}$ The motivation to write these memoirs generally was not political; rather, the authors sought to leave personal testimonies for the second and third generations. Matthew Tovian, for example, wrote his (unpublished) memoirs at his home in West Hartford, Connecticut, in December 1993. Although Tovian, who escaped occupied Poland in 1941, had had to endure forced labor and hunger in Soviet Central Asia, his conclusion is rather laconic: "Looking back, I have no bad feelings about the Soviets. They provided a place for us to go. They let us into their country, unlike what happened in some other countries. It was no picnic, but I survived." 87

Laura Jockusch is Feodor Lynen Minerva Postdoctoral Fellow at the Hebrew University of Jerusalem and Ben-Gurion University of the Negev, Beer Sheva. Her publications include: "A Folk Monument to Our Destruction and Heroism: Jewish Historical Commissions in the Displaced Persons Camps of Germany, Austria, and Italy" (2010); “Appell an das Weltgewissen': Jüdische Holocaustdokumentation in der frühen Nachkriegszeit am Beispiel Frankreichs" (2009); "Khurbn Forshung: Jewish Historical Commissions in Europe, 19431949" (2007); "Chroniclers of Catastrophe: History Writing as a Jewish Response to Persecution before and after the Holocaust" (2008); and Collect and Record! Jewish Holocaust Documentation in Postwar Europe (forthcoming 2011). Her current research focuses on Holocaust survivors' conceptions of retributive justice in postwar Europe. 
Tamar Lewinsky teaches in the Department of Jewish Studies at the University of Basel. Her publications include Displaced Poets: Jiddische Schriftsteller im Nachkriegsdeutschland, 1945-1951 (2008); "Jewish Displaced Persons from Poland in Occupied Germany" (forthcoming, 2011); "Dangling Roots? Yiddish Language and Culture in the German Diaspora" (2010); "Jiddische Kultur im Transit: Osteuropäisch-jüdische Displaced Persons" (2008); (with Anthony Kauders) "Neuanfang mit Zweifeln" (2006); and "Yidishe bilder: Eine jiddische Illustrierte zwischen Riga, Gräfelfing und Jerusalem" (2008). She is currently compiling and translating an annotated anthology of Yiddish-language DP literature.

\section{Notes}

1. Sławomir Grünberg and Roman Podgursky, Saved by Deportation: An Unknown Odyssey of Polish Jews (Los Angeles: Seventh Art Releasing, 2007), DVD.

2. The number of Polish Jews under Soviet control-including both refugees and deportees-may have been about 400,000. See David Engel, "Poland since 1939," in The YIVO Encyclopedia of Jews in Eastern Europe, vol. 2, ed. Gershon Hundert (New Haven: Yale University Press, 2008), 1404; Jan T. Gross, "The Sovietization of Western Ukraine and Western Byelorussia," in Jews in Eastern Poland and the USSR, 1939-1946, ed. Norman Davies and Antony Polonsky (London: Macmillan Academic and Professional, 1991), 73. Other estimates run as high as half a million; see Joseph Litvak, "Jewish Refugees from Poland in the USSR," in Bitter Legacy: Confronting the Holocaust in the USSR, ed. Zvi Gitelman (Bloomington: Indiana University Press, 1997), 147; idem, Plitim yehudim mipolin be-brit ha-moatsot: 1939-1946, Ph.D. thesis, Hebrew University Jerusalem, 1983; Keith Sword, "The Welfare of Polish Jewish Refugees in the USSR, 1941-1943: Relief Supplies and their Distribution," in Davies and Polonsky, Jews in Eastern Poland, 145.

3. Albert Kaganovitch, "Jewish Refugees and Soviet Authorities during World War II," Yad Vashem Studies 38, no. 2 (2010), forthcoming.

4. Litvak, "Jewish Refugees from Poland in the USSR," 133.

5. An additional 30,000 Polish Jews left the Soviet Union in 1957. See Engel, "Poland since 1939," 1406.

6. Dan Diner, Gegenläufige Gedächtnisse: Über Geltung und Wirkung des Holocaust (Göttingen: Vandenhoeck \& Ruprecht, 2007), $24 f$.

7. We wish to thank Atina Grossmann for her encouragement and support. In the context of several conferences and workshops over the years Grossmann pointed to the need for a study of Polish Jews' postwar memory of survival in the Soviet Union, and especially of the role that the Soviet experience played in the memory of Jewish Displaced Persons.

8. On these developments see Jan T. Gross, "Poland Abandoned" (chap. 1) in Fear: Anti-Semitism in Poland after Auschwitz (New York: Random House, 2006); Krystyna Kersten, The Establishment of Communist Rule in Poland, 1943-1948 (Berkeley: University of California Press, 1991) and Norman Davies, God's Playground: A History of Poland (Oxford: Clarendon Press 1981), 2: 556-77.

9. Joanna B. Michlic, "Żydokomuna-Anti-Jewish Images and Political Tropes in Modern Poland," Simon Dubnow Institute Yearbook 4 (2005): 303-29; and idem, Poland's 
Threatening Other: The Image of the Jew 1880 to the Present (Lincoln: University of Nebraska Press, 2006) chap. 6.

10. Estimates of the number of Jews killed in antisemitic attacks during this early postwar period range from 500 to 1500 . For a discussion of these figures see Gross, Fear, 35, and David Engel, "Patterns of anti-Jewish Violence in Poland, 1944-1946," Yad Vashem Studies 26 (1998): 43-85.

11. See for example David Engel, "The Reconstruction of Jewish Communal Institutions in Postwar Poland: The Origins of the Central Committee of Polish Jews, 1944-1945," East European Politics and Societies 10 (1996): 85-107. See also Natalia Aleksiun, "Rescuing a Memory and Constructing a History of Polish Jewry: Jews in Poland 1944-1950," Jews in Russia and Eastern Europe 1-2 (2005): 5-27; idem, "The Vicious Circle: Jews in Communist Poland, 1944-1956," in Jews and the State: Dangerous Alliances and the Perils of Privilege, ed. Ezra Mendelsohn (Studies in Contemporary Jewry 19) (New York: Oxford University Press, 2003), 157-80; idem, "Zionists and Anti-Zionists in the Central Committee of the Jews in Poland: Cooperation and Political Struggle, 1944-1950," Jews in Eastern Europe 33 no. 2 (1997): 33-50; Israel Gutman, Ha-yehudim be-polin ahare milhemet olam ha-shniyah (Jerusalem: Merkaz Zalman Shazar, 1985); Hana Shlomi, "Reshit hitargenut shel yehude Polin be-shilhe milhemet-olam ha-shniyah," Gal Ed 2 (1975): 287-331; and Michael C. Steinlauf, Bondage to the Dead: Poland and the Memory of the Holocaust (Syracuse, NY: Syracuse University Press, 1997).

12. David Engel, "Poland since 1939," 1406, and idem, Beyn shihrur li-verikhah: Nitsole ha-shoah be-Polin ve-ha-ma'avak 'al hanhagatam, 1944-1946 (Tel Aviv: Universitat Tel Aviv, 1996), 40.

13. On these conditions see Gross, Fear, "The Unwelcoming of Jewish Survivors" (chap. 2).

14. On the history of the Brichah in Poland see: Yehuda Bauer, Flight and Rescue: Brichah, the Organized Escape of the Jewish Survivors of Eastern Europe, 1944-1948 (New York: Random House, 1970), 113-51.

15. In summer 1946, 240,000 were registered with the Central Committee of Polish Jews; a year later the number had dropped to 90,000. Engel, "Poland since 1939," 1406-1407. See also Albert Stankowski and Piotr Weiser, "The Demographic Consequences of the Holocaust," in The Aftermath of the Holocaust: Poland 1944-2008, ed. Feliks Tych and Monika Adamczyk-Garbowska (Lublin: Marie Curie-Sklodowska University Press, forthcoming 2011).

16. On the Central Jewish Historical Commission see Natalia Aleksiun, "The Central Jewish Historical Commission in Poland, 1944-1947," in Making Holocaust Memory (Polin 20) ed. Gabriel N. Finder, et al. (Oxford: Littman Library of Jewish Civilization, 2007), 74-97; and Feliks Tych, "The Emergence of Holocaust Research in Poland: The Jewish Historical Commission and the Jewish Historical Institute (ŻIH), 1944-1989," in Holocaust Historiography in Context: Emergence, Challenges, Polemics and Achievements, ed. David Bankier and Dan Michman (Jerusalem: Yad Vashem, 2008), 232. On other cultural activity in postwar Poland, see Nathan Cohen, "The Renewed Association of Yiddish Writers and Journalists in Poland, 1945-48," in Yiddish After the Holocaust, ed. Joseph Sherman (Oxford, UK: Boulevard, 2004); and Elvira Grözinger and Magdalena Ruta, eds., Under the 
Red Banner: Yiddish Culture in the Communist Countries in the Postwar Era (Wiesbaden: Harrassowitz, 2008).

17. For example, Noe Grüss, "Bagegenishn mit fraynt," Dos naye lebn no. 4, 1945; and "Repatriatsye fun Ratnfarband farlengert," Dos naye lebn no. 23, 1945.

18. Yitskhok Varshavski, "Yidishe studentn fun Poyln af sovetisher erd," Dos naye lebn no. 10, 1947.

19. Nokhem Strokhman, "Far yidish-sovetisher frayntshaft," Dos naye lebn no. 38, 1947. A similar apprehension of the positive image of the Russian war effort is apparent in the memoir of Noe Grüss, Tsvishn fraynt: Finf yor in land vos hot bazigt dem hitlerizm (Entre amis: Souvenirs des années 1939-1945) (Paris: Oyfsnay, 1953).

20. Ber Mark, "Mir kumen tsurik," Dos naye lebn no. 10, 1946.

21. M. Valdman, "Arele kumt aheym," in Lomir kinder lernen: Bletlekh fun a khrestomatye, vols. 11-12 (Lodz: Central Committee of Liberated Jews in Poland, 1947), 28. Our thanks are due to Evita Wiecki for pointing out this story to us. Wiecki is currently working on a much-needed analysis of Yiddish textbooks.

22. Ibid., 30-32.

23. This also holds true for the publications of the Yidish Bukh publishing house during this period. See: Joanna Nalewajko-Kulikov, "The Last Yiddish Books Printed in Poland: Outline of the Activities of Yidish Bukh Publishing House," in Grözinger and Ruta, Under the Red Banner, 112 and 121.

24. Magdalena Ruta, "The Principal Motifs of Yiddish Literature in Poland, 1945-1949: Preliminary Remarks," in Grözinger and Ruta, Under the Red Banner, 167; for analysis and examples of the various voices in early Holocaust literature, see ibid., 172-82.

25. Yitzkhok Perlov, Undzer like-khame: Lider 1939-1946, (Munich: Poyle-Tsiyen in Daytshland, 1947), 46. The poem was written in 1942 and published for the first time in the 1946 anthology Yidishe shriftn in Lodz.

26. Magdalena Ruta, "The Principal Motifs," 171.

27. Ibid., 172 .

28. Dovid Sfard, "Tsum tsurikker fun undzere shrayber," in Yidishe shriftn, ed. Leo Finkelstein (Lodz: Farayn fun yid. literatn un zshurnalistn in Poyln, 1946), 55 and 59.

29. Ruta, "The Principal Motifs," 169. See also Joanna Nalewajko-Kulikov, Obywatel Jidyszlandu: Rzecz o żydowskich komunistach w Polsce (Warsaw: Neriton, 2009).

30. Some 40,000-50,000 Jews emigrated from Poland between July and December 1945; 100,000 left in a second wave between May and September 1946; an estimated 120,000 of these went to the West with the help of the Brichah. See Engel, "Poland since 1939," 1407. See also Stankowski and Weiser, "Demographic Consequences."

31. Atina Grossmann, Jews, Germans, and Allies: Close Encounters in Occupied Germany (Princeton: Princeton University Press, 2007), 316. 
32. Ze'ev Mankowitz, Between Memory and Hope: The Survivors of the Holocaust in Occupied Germany (New York: Cambridge University Press, 2002), 291. Polish Jews comprised an estimated 80 percent of this Jewish DP population. See Malcolm Proudfoot, European Refugees: A Study in Forced Population Movement (Evanston: Northwestern University Press, 1956), 340; Zorah Warhaftig, The Uprooted: Jewish Refugees and Displaced Persons after Liberation (New York: Institute of Jewish Affairs of the American Jewish Congress and World Jewish Congress, 1946), 50; Leonard Dinnerstein, America and the Survivors of the Holocaust (New York: Columbia University Press, 1982), 279.

33. This term is of biblical origin (Genesis 32:9; 2 Kings 19:30-31; Jeremiah 31:7); as of 1943 Jews in the Yishuv used it to describe those who would survive the persecutions in Europe. After the war, the survivors themselves used this term to express their separate group identity as survivors of the cataclysm. Mankowitz, Life between Memory and Hope, 1; and Dalia Ofer, "From Survivors to New Immigrants: She'erit Hapletah and Aliyah," in She'erit Hapletah, 1944-1948: Rehabilitation and Struggle, ed. Israel Gutman and Avital Saf (Jerusalem: Yad Vashem, 1990), 304-36.

34. Mordkhe Libhaber, “A kapitl geszichte gejt farlorn," Ibergang, June 29, 1947.

35. Ibid.

36. Perlov, Undzer like-khame: Lider 1939-1946, 113.

37. Ibid., 114.

38. This tone of gratitude reverberates throughout his autobiography Mayne zibn gute yor: Roman fun a freylekhn polit in Ratnfarband (Tel Aviv: Farlag kultur-lige, 1959).

39. Mendel Mann, Yerushe (Regensburg: Yidishe zetser, 1947), 35-42.

40. Meylekh Tshemni, Uzbekistan (Munich: EUCOM Civil Affairs, 1949), 8.

41. Personal Papers of Meylekh Tshemni, Jewish National and University Library Jerusalem, Arc. 4, 1533, Kaczerginski to Tshemni, Paris, March 1950.

42. On the history of the Commission in Munich see Laura Jockusch, "Khurbn ForshungJewish Historical Commissions in Europe 1943-1949," Yearbook of the Simon Dubnow Institute 6 (2007): 441-73; idem, "A Folk Memorial to Our Destruction and Heroism: Jewish Historical Commissions in the Displaced Persons Camps of Germany, Austria and Italy," in "We Are Here": New Approaches to Jewish Displaced Persons in Postwar Germany, ed. Avinoam J. Patt and Michael Berkowitz (Detroit: Wayne State University Press, 2010), 31-73; and idem, "'Collect and Record! Help to Write the History of the Latest Destruction!: Jewish Historical Commissions in Europe," Ph.D. thesis, New York University, 2007; Ada Schein, “'Everyone can hold a pen'-The Documentation Project in the DP Camps in Germany," in Bankier and Mikhman, Holocaust Historiography in Context, 103-34.

43. See for example: Yad Vashem Archives Jerusalem [hereafter YVA] M1E/319, Yosef Leszcz, September 5, 1946; YVA M1E/320, Beyle Shnep, September 5,1946; and YVA M1E/ 315, Ben-Zion Rutkin, September 5, 1946.

44. Eliezer Ushtun, n.d., YVA M1E/310.

45. Shlomo Tessler, Gräfenberg, n.d., YVA M1E/415. 
46. Moniek Vilner, Gräfenberg, n.d., YVA M1E/435.

47. Simkhe Binshtok, Stuttgart, n.d., YVA M1E/707.

48. Dawid Hofman, Stuttgart, n.d., YVA M1E/709.

49. Ze'ev Mankowitz, "The Formation of the She'erit Hapleita: November 1944-July 1945" Yad Vashem Studies 20 (1990): 337-70; Yehuda Bauer, "The Initial Organization of the Holocaust Survivors in Bavaria," Yad Vashem Studies 8 (1970): 127-57.

50. Hagit Lavsky, New Beginnings: Holocaust Survivors in Bergen-Belsen and the British Zone in Germany, 1945-1950 (Detroit: Wayne State University Press, 2002).

51. Mankowitz, Life between Memory and Hope, 291.

52. "Di velkhe firn on mitn gezelshaftlekhn un politishn lebn bay der sheyres-hapleyte in der amerikaner zone," Yidishe bilder 9, no. 20 (1948): 8f.

53. See Fun letstn khurbn, vols. 1-10 (August 1946-December 1948).

54. On Fun letstn khurbn see Boaz Cohen, "Representing the Experiences of Children in the Holocaust: Children's Survivor Testimonies Published in Fun Letstn Hurbn, Munich 1946-1949," in Patt and Berkowitz, "We Are Here," 74-97.

55. On commemoration in the DP camps see Gabriel Finder, "Yizkor! Commemoration of the Dead by Jewish Displaced Persons in Postwar Germany," in Between Mass Death and Individual Loss: The Place of the Dead in Twentieth-Century Germany, ed. Alon Confino, Paul Betts, and Dirk Schumann (New York: Berghahn Books, 2008), 232-57; Mankowitz, Life between Memory and Hope, 192-225; Margarete Myers Feinstein, Holocaust Survivors in Postwar Germany, 1945-1957 (Cambridge: Cambridge University Press, 2010), 73-85.

56. Kaganovitch, "Jewish Refugees."

57. “Akhtung! Grodner yidn!” Ibergang, February 25, 1947. Emphasis in original.

58. Benjamin Orenstein, Churban Czenstochow ([Munich?]: Central Farwaltung fun der Czenstochower Landsmanszaft in der Amerikaner Zone in Dajczland, 1948); idem., Churban Treblinka, Falenic, Otwock, Karczew (Bamberg: Farvaltung fun Otvotsker, Falenitser un Kartshever landslayt in der Amerikaner zone in Daytshland, 1948); Meir Grinszpan, Majn Sztetl Kostopol. Poeme (Neu-Ulm: n.p., 1947), xiv.

59. Jack Kugelmass and Jonathan Boyarin, From a Ruined Garden: The Memorial Books of Polish Jewry (Bloomington: Indiana University Press in association with the United States Holocaust Memorial Museum, 1998). See especially the introduction.

60. See Saved by Deportation.

61. Tamar Lewinsky, Displaced Poets: Judische Schriftsteller in Nachkriegsdeutschland, 1945-1951 (Göttingen: Vadenhoeck \& Ruprecht, 2008), 156-59.

62. A similar tendency is notable in the pace at which the Central Historical Commission in Munich collected survivor testimonies. Of 2,500 testimonies collected between 1945 and 1948, roughly 1,500 were gathered in the first year and fewer than 1,000 in the following twenty-five months. Jockusch, Collect and Record, 279. 
63. Feinstein, Holocaust Survivors in Postwar Germany, 78-81; Mankowitz, Life between Memory and Hope, 211-12.

64. Letter from Lucy Shildkret, American Jewish Historical Society P-675, box 55, folder 3, Munich, November 17, 1946.

65. Dinnerstein, America and the Survivors of the Holocaust, 236.

66. "Mendel Mann," in Leksikon fun der nayer yidisher literatur, vol. 5 (New York: Congress for Jewish Culture, 1963), 431.

67. Archives of the International Tracing Service (ITS) at Bad Arolsen, Germany, C/M-1 Germany, Mendel Mann.

68. Meylekh Tshemni, Vunder in vander: Bletlekh fun mayn togbukh: September 1939september 1969 (Ramat Gan: Eygns, 1971), 306.

69. Ibid., 308-309.

70. Ibid., 309 .

71. Archives of the Yeshiva University New York, Bernstein Collection, box 5, folder 8, "A grupe yidishe kulturtuers," October 30, 1950, p. 3.

72. On the Erlich-Alter Affair, see Daniel Blatman, For Our Freedom and Yours: The Jewish Labour Bund in Poland 1939-1949 (London: Vallentine Mitchell, 2003), 69-89.

73. Jerzy G. Gliksman, "Jewish Exiles in Soviet Russia (1939-1943)," parts 1-3, May and July 1947, YIVO RG 1464, Jerzy Gliksman Collection, box 4, folder 41.

74. Jerzy G. Gliksman, Tell the West: An Account of His Experiences as a Slave Laborer in the Union of Soviet Socialist Republics (New York: Gresham Press, 1948). A "Publishers' Note" introducing the book emphasized that "although Soviet Corrective Labor Camps (lagers) are not places of calculated atrocity like the former concentration camps of Germany, they are-as this book and camp death rates show-institutions where men and women are ruthlessly and mercilessly exploited beyond the limits of human endurance."

75. Gliksman, Tell the West, n.p.

76. Betsalel Terkel, Tvishn shakaln: Shive medorey "gan-eydn" (Buenos Aires: Tsentralfarband fun poylishe yidn in Argentine, 1959), n.p.

77. Idem, Di zun fargeyt baym Amu-Darya (Buenos Aires: Tsentral-farband fun poylishe yidn in Argentine, 1963), 15.

78. Ibid., 15-16.

79. Ovadye Feld, 5 yor in sotsyalistishn foterland (Tel Aviv: n.p., 1972), 7-8.

80. Meir Korzen, "Problems Arising out of Research into the History of Jewish Refugees in the USSR during the Second World War," Yad Vashem Studies 3 (1959), 119. See also Bernard D. Weinryb, "Polish Jews under Soviet Rule," in The Jews in Soviet Satellites, ed. Peter Meyer, et al. (Syracuse: Syracuse University Press, 1953). 
81. On the anti-Semitic campaign of 1968 in Poland and its consequences for the Jewish community see for example: Leszek W. Głuchowski and Antony Polonsky, eds., 1968: Forty Years After (Polin 21) (Oxford: Littman Library of Jewish Civilization, 2009).

82. Dovid Sfard, Mit zikh un mit andere: Oytobiografye un literarishe eseyen (Jerusalem: Farlag "Yerusholaimer almanakh," 1984), 154.

83. Ibid., 108-109.

84. Ibid., 96.

85. Ibid., 134.

86. To list just a few examples: Donna J. Azrieli, ed., One Step Ahead: David J. Azrieli (Azrylewicz) Memoirs, 1939-1950 (Jerusalem: Yad Vashem, 2001); Isabelle Choco-Sztrauch-Galewska, et al., Stolen Youth: Five Women's Survival of the Holocaust (Jerusalem: Yad Vashem, 2005); Alan Elsner, Guarded by Angels: How My Father and Uncle Survived Hitler and Cheated Stalin (Jerusalem: Yad Vashem, 2005); Mark Ettinger, Erinnerungen: Von Warschau durch die Sowjetrepublik Komi nach Astrakhan, 1922-1999 (Konstanz: Hartung-Gorre, 2005); Zev Katz, From the Gestapo to the Gulags: One Jewish Life (London: Vallentine Mitchell, 2004); Hanna Davidson Pankowsky, East of the Storm: Outrunning the Holocaust in Russia (Lubbock: Texas Tech University Press, 1999); Henry Skorr, Through Blood and Tears: Surviving Hitler and Stalin (London: Vallentine Mitchell, 2006); Saul Szternfeld, Halom ben gederot (Tel Aviv: Halonot, 1999); Rachela Tytelman Wygodzki, The End and the Beginning (August 1939-July 1948) (Bellevue: R.T. Wygodzki, 1998).

87. “Matthew’s Story," YVA O 33/ 4053, December 1993, p. 51. 